\title{
HUBUNGAN FREKUENSI KONSUMSI KARBOHIDRAT DENGAN KEJADIAN KARIES GIGI PADA ANAK PRASEKOLAH
}

\section{Correlation of Frequency of Carbohydrate Consumption with the Event of Dental Caries in Preschool Children}

\author{
Diah Fauzia Zuhroh ${ }^{1}$, Urfiyanah ${ }^{2}$ \\ 1,2 \\ Program Studi Ilmu Keperawatan Universitas Muhammadiyah Gresik \\ Alamat Korespondensi : Prodi Ilmu Keperawatan dan Ners UMG \\ Jl. Proklamasi No. 54 Gresik, JawaTimur - Indonesia \\ E-mail: fauzia_diah@umg.ac.id
}

\begin{abstract}
ABSTRAK
Masalah terbesar yang dihadapi penduduk Indonesia seperti di negara berkembang lainnya di bidang kesehatan gigi dan mulut penyakit jaringan yaitu karies gigi atau caries dentis di samping penyakit gusi. Tujuan penelitian ini untuk menganalisis hubungan konsumsi karbohidrat dengan kejadian karies gigi di TK Asmaul Husna Arosbaya Bangkalan Madura.

Jenis penelitian ini adalah analitik dengan desain cross sectional. Populasi dalam penelitian ini seluruh siswa-siswi sebanyak 60 siswa dan jumlah sampel 53 siswa yang diambil menggunakan tekhnik accidental sampling. Variabel independen konsumsi karbohidrat dan variabel dependen karies gigi. Pengumpulan data dengan menyebar kuesioner, pengolahan data editing, coding, scoring dan tabulating, analisa data dengan uji statistik Chisquare menggunakan SPSS 16.

Hasil penelitian diperoleh bahwa siswa yang mengkonsumsi karbohidrat sering 42 siswa (79,2\%). Sedangkan yang mengkonsumsi karbohidrat jarang 11 siswa (20,8\%). Siswa yang tidak mengalami karies gigi 18 siswa (34,0\%). Sedangkan yang mengalami karies gigi 35 siswa $(66,05)$. Hasil uji statistik chisquare dengan SPSS 16, $\mathrm{p}=0,001$ dimana $\mathrm{p}<\alpha(0,05)$ yang berarti Hi diterima.

Kesimpulan dalam penelitian ini yaitu ada hubungan frekuensi konsumsi karbohidrat dengan kejadian karies gigi di TK Asmaul Husna Arosbaya Bangkalan Madura.

Kata kunci : konsumsi, karbohidrat, karies gigi

\section{ABSTRACT}

The biggest problem faced by the population of Indonesia as in other developing countries in the field of dental health and oral tissue diseases is dental caries or dental caries in addition to gum disease. the purpose of this study was to analyze the relationship between carbohydrate consumption and the incidence of dental caries in TK Asmaul Husna Arosbaya Bangkalan Madura.

This type of research is analytic with cross sectional design. The population in this study were 60 students and a sample of 53 students were taken using accidental sampling technique. The independent variable is carbohydrate consumption and the dependent variable is dental caries. Collecting data by distributing questionnaires, processing data editing, coding, scoring and tabulating, analyzing data by using a Chi-square statistical test using SPSS 16.

The results showed that students who consumed carbohydrates were often 42 students (79.2\%). Whereas those who consumed carbohydrates were rarely 11 students (20.8\%). Chi-square statistical test results with SPSS 16, $p=0.001$ where $p<\alpha(0.05)$ which means Hi is accepted.

The conclusion in this study is that there is a relationship between carbohydrate consumption and the incidence of dental caries in TK Asmaul Husna Arosbaya Bangkalan Madura.
\end{abstract}

Keywords : consumption, carbohydrate, dental caries 


\section{PENDAHULUAN}

Masalah terbesar yang dihadapi penduduk Indonesia seperti di negara berkembang lainnya di bidang kesehatan gigi dan mulut penyakit jaringan yaitu karies gigi atau caries dentis di samping penyakit gusi. (Dewanti, 2012). Hasil Riset Kesehatan Dasar atau Riskesdas 2018 menyebutkan bahwa $93 \%$ anak usia dini, yakni dalam rentang usia 5-6 tahun mengalami gigi berlubang, ini berarti hanya 7\% anak indonesia yang bebas dari masalah karies gigi. Hasil Riskesdas 2018 ini juga menunjukkan bahwa rata-rata anak-anak usia 4-6 tahun mengalami lubang pada delapan giginya. (Riskesdas, 2018). Kesehatan adalah aspek yang sangat penting dalam kehidupan manusia, termasuk bagi anak-anak. Umumnya orang kurang menghargai pentingnya menjaga kesehatan. Akan tetapi tidak dapat dipungkiri bahwa tanpa kesehatan yang cukup, kita tidak akan mampu menjalankan aktivitas sehari-hari dengan baik. Dengan kata lain, kualitas hidup kita akan menurun tanpa adanya kesehatan tubuh (Galuh, 2018).

Anak Prasekolah merupakan anak yang berusia 4-6 tahun yang sudah memiliki kematangan dalam berbagai fungsi motorik dan sudah berkembang intelektual dan sosioemosionalnya. Pada usia ini anak sering kali mengabaikan kesehatannya, terutama kesehatan gigi. Kerusakan pada gigi seperti karies, meloklusi atau gigi tidak sejajar, plak gigi, karang gigi dapat mempengaruhi kesehatan anggota tubuh lain, bahkan jika gigi anak sakit kemungkinan nafsu makan anak akan menurun, hal itu perlu diperhatikan sejak dini oleh orang tua, sebagai panutan, kontroler, serta motivator orang tua memiliki peran yang penting untuk kesehatan gigi anaknya, jika tidak diperhatikan maka kesehatan gigi anak berkembang menjadi suatu masalah yang dapat menganggu masa depan anak tersebut. Purwanto, (2015)

Hasil yang didapatkan dari wawancara dengan kepala sekolah TK Asmaul Husna Arosbaya Bangkalan Madura siswanya sebesar 60 orang siswa, hasil dari data observasi yang diambil langsung dari TK Asmaul Husna Arosbaya Bangkalan Madura sebesar 60 orang siswa yang diobservasi dan yang mengalami karies gigi 53 orang siswa atau $88 \%$ maka masalah penelitian adalah tingginya kasus karies gigi di TK Asmaul Husna Arosbaya Bangkalan Madura. Tujuan penelitian ini untuk menganalisis hubungan konsumsi karbohidrat dengan kejadian karies gigi di TK Asmaul Husna Arosbaya Bangkalan Madura.

\section{METODE}

Jenis penelitian ini adalah penelitian analitik atau observasi dengan menggunakan rancangan Cross Sectional. Cross Sectional adalah jenis penelitian yang menekankan waktu pengukuran atau observasi data variabel independen dan dependen hanya satu kali pada saat satu saat (Nursalam, 2013). Populasi dalam penelitian ini seluruh siswa-siswi sebanyak 60 siswa dan jumlah 
sampel 53 siswa yang diambil menggunakan tekhnik accidental sampling. Variabel independen konsumsi karbohidrat dan variabel dependen karies gigi. Pengumpulan data dengan menyebar kuesioner, pengolahan data editing, coding, scoring dan tabulating, analisa data dengan uji statistik Chisquare menggunakan SPSS 16.

\section{HASIL DAN PEMBAHASAN}

\section{Data Umum}

Tabel 1.Distribusi frekuensi berdasarkan umur siswa-siswi TK Asmaul Husna Madura

\begin{tabular}{llcc}
\hline No. & $\begin{array}{l}\text { Karakteristik } \\
\text { Responden }\end{array}$ & n & $\mathbf{( \% )}$ \\
\hline 1. & Umur & & \\
& 4 tahun & 10 & 18.9 \\
& 5 tahun & 24 & 45.3 \\
& 6 tahun & 19 & 35.8 \\
\hline 2. & Jenis Kelamin & & \\
& Laki-laki & 35 & 66.0 \\
& Perempuan & 18 & 34.0 \\
\hline & Jumlah & $\mathbf{5 5 3}$ & $\mathbf{1 0 0}$ \\
\hline
\end{tabular}

Sumber data : Data primer (2020)

Berdasarkan tabel 1 dapat dijelaskan bahwa sebagian besar murid TK Asmaul Husna Arosbaya Bangkalan Madura berumur 5 tahun, dengan jumlah 24 siswa (45.3\%), siswa berjenis kelamin laki-laki sebanyak 35 $(66.0 \%)$.

\section{Data Khusus}

\section{Konsumsi Karborhidrat Dengan Kejadian Karies Gigi Pada Anak Prasekolah Di TK}

Tabel 2. Frekuensi konsumsi karbohidrat

\begin{tabular}{ccc}
\hline $\begin{array}{c}\text { Konsumsi } \\
\text { Karbohidrat }\end{array}$ & n & \% \\
\hline Sering & 42 & 80.0 \\
Jarang & 11 & 20.0 \\
\hline Total & $\mathbf{5 3}$ & $\mathbf{1 0 0}$ \\
\hline
\end{tabular}

Berdasarkan tabel 2 dapat dijelaskan bahwa sebagian besar siswa di TK Asmaul Husna Arosbaya Bangkalan Madura, yang sering mengkonsumsi karbohidrat dengan jumlah 42 siswa (76,2\%). Menurut Khila (2017) Sebagian besar makanan yang dikonsumsi oleh manusia sehari-hari terdiri atas karbohidrat, contohnya adalah nasi, roti, kentang, dan lain sebagainya. Karbohidrat merupakan sumber energi yang utama selain lemak dan protein. Karbohidrat utama yang terdapat dalam makanan adalah amilum atau pati, suatu polisakarida yang dibuat oleh tumbuhan dengan cara fotosintesa. Dalam tubuh binatang maupun manusia juga terdapat cadangan karbohidrat yang disimpan di hati dan otot dalam bentuk glikogen.

Menurut hasil penelitian Sukrama (2017) sebanyak 19 orang (23.0\%) memiliki tingkat konsumsi karbohidrat yang sering. konsumsi karbohidrat yang sering ditemukan pada anak prasekolah yang disebabkan karena kegemaran mengkonsumsi makanan ysng manis-manis. Menurut peneliti dilapangan dimana disekitar lingkungan sekolah banyak sekali penjual makanan yang menjual makanan atau minuman yang digemari oleh para anak-anak usia prasekolah yang banyak mengandung karbohidrat yang sangat tidak baik jika dikonsumsi terlalu berlebihan tanpa pengawasan dari orang tua, sehingga anak-anak dengan leluas mengkonsumsi makanan dan minuman tersebut. 
2. Kejadian Karies Gigi Pada Anak Prasekolah Di TK Asmaul Husna Arosbaya Bangkalan Madura

Tabel 3. Frekuensi Karies Gigi

\begin{tabular}{ccc}
\hline \multicolumn{1}{c}{ Karies Gigi } & $\mathbf{n}$ & $\mathbf{\%}$ \\
\hline Tidak Karies Gigi & 18 & 34 \\
Karies Gigi & 35 & 66 \\
\hline \multicolumn{1}{c}{ Total } & $\mathbf{5 3}$ & $\mathbf{1 0 0}$ \\
\hline
\end{tabular}

Berdasarkan tabel 3 dapat dijelaskan bahwa jumlah siswa yang mengalami karies gigi sebanyak 35 siswa (66.0\%). Sedangkan yang tidak mengalami karies gigi sebanyak 18 siswa (34.0\%). Menurut hasil penelitian Ramayanti (2013) Karies gigi adalah penyakit pada jaringan karies gigi yang ditandai oleh rusaknya email dan dentin disebabkan oleh aktivitas dalam mulut (karbohidrat) merupakan substrat yang difermentasikan oleh bakteri untuk mendapatkan energi. Sukrosa dan glukosa dimetabolismekan sedemikian rupa sehingga terbentuk polisakari da intrasel dan ekstrasel sehingga bakteri melekat pada permukaan gigi. Selain itu sukrosa juga menyediakan cadangan energi bagi metabolisme kariogenik.

Menurut Hidayat dan Astrid (2016) Karies gigi merupakan penyakit jaringan keras gigi, yaitu email, dentin, yang disebabkan oleh aktivitas suatu jasad renik dalam suatu karbohidrat yang dapat diragikan. Tandanya ada demineralisasi jaringan keras gigi yang kemudian diikuti oleh kerusakan bahan organiknya. Hasil Riset Kesehatan Dasar atau Riskesdas 2018 menyebutkan bahwa 93\% anak usia dini, yakni dalam rentang usia 5-6 tahun mengalami gigi berlubang, ini berarti hanya 7\% anak indonesia yang bebas dari masalah karies gigi. Hasil Riskesdas 2018 ini juga menunjukkan bahwa rata-rata anak-anak usia 4-6 tahun mengalami lubang pada delapan giginya. Hal ini menurutnya biasa memengaruhhi status gizi anak karena gigi berlubang membuat anak menolak untuk makan.

Karies Gigi banyak terjadi pada anak usia prasekolah seperti yang terjadi di TK Asmaul Husna Arosbaya Bangkalan Madura, banyak menderita penyakit karies gigi karena anak-anak cenderung lebih menyukai makanan-makanan yang banyak mengandung karbohidrat (Permen, coklat, biskuit, es cream dan makanan manis lainnya) yang berlebihan dikonsumsi oleh anak-anak TK Asmaul Husna Arosbaya Bangkalan Madura. Pada umumnya keadaan kebersihan mulut anak lebih buruk karena anak lebih banyak mengonsumsi makanan dan minuman yang menyebabkan karies dibandingkan orang dewasa. Hasil yang didapatkan dari wawancara dengan kepala sekolah TK Asmaul Husna Arosbaya Bangkalan Madura siswanya sebesar 60 orang siswa, hasil dari data observasi yang diambil langsung dari TK Asmaul Husna Arosbaya Bangkalan Madura sebesar 60 orang siswa yang diobservasi dan yang mengalami karies gigi 53 orang siswa atau $88 \%$ maka masalah penelitian adalah tingginya kasus karies gigi di TK Asmaul Husna Arosbaya Bangkalan Madura. Hasil Penelitian menyebutkan bahwa siswa yang mengalami karies gigi 
sebagian besar sering mengkonsumsi karbohidrat dibanding jarang mengkonsumsi karbohidrat.

\section{Hubungan Frekuensi Konsumsi} Karbohidrat Dengan Kejadian Karies Gigi Pada Anak Prasekolah Di TK Asmaul Husna Arosbaya Bangkalan Madura

Tabel 4. Tabulasi silang karbohidrat dengan kejadian karies gigi

\begin{tabular}{lcccccc}
\hline $\begin{array}{l}\text { Frekuen } \\
\text { si }\end{array}$ & \multicolumn{5}{c}{ Karies Gigi } \\
\cline { 2 - 7 } $\begin{array}{l}\text { Konsum } \\
\text { si } \\
\text { Karbohi } \\
\text { drat }\end{array}$ & $\begin{array}{c}\text { Tidak } \\
\text { Karies } \\
\text { Gigi }\end{array}$ & \multicolumn{2}{c}{$\begin{array}{c}\text { Karies } \\
\text { Gigi }\end{array}$} & Total \\
\cline { 2 - 7 } Sering & 10 & 23.8 & 32 & 76.2 & 53 & 100 \\
\cline { 2 - 7 } Jarang & 9 & 81.8 & 2 & 18.2 & & \\
\hline \multicolumn{6}{c}{$\boldsymbol{P}$ Value } & $: 0,01$ \\
\hline
\end{tabular}

Berdasarkan hasil uji statistik $C h i$ Square dengan SPSS 16, didapat nilai pvalue $<\alpha(0,01<0,05)$, yang berarti Ho ditolak maka Hi diterima dengan demikian ada hubungan konsumsi karbohidrat dengan kejadian karies gigi pada anak prasekolah di TK Asmaul Husna Arosbaya Bangkalan Madura. Menurut hasil penelitian Diajeng 2016, kejadian karies gigi pada anak usia prasekolah sebanyak $83,2 \%$ yang mengalami karies gigi hal tersebut dikarenakan anakanak usia prasekolah lebih menyukai makanan-makanan yang engandung karbohidrat, pada penelitian di kanada mengungkapkan bahwa karies gigi yang tidak diberikan pengobatan menyebabkan $48 \%$ anak mengeluh sakit gigi, $43 \%$ anak memiliki masalah makan makanan tertentu, $61 \%$ anak makan sedikit atau tidak menyelesaikan makanan yang disajikan 35\% anak tidak bisa tidur nyenyak karena rasa sakit yang timbul karena karies gigi. Menurut Teori Koswara 2009, ada tiga mekanisme terjadinya karies gigi yang disebabkan oleh makanan yang mengandung karbohidrat berlebihan yaitu teori protheolysis, proteolitic-chelation dan chemoparasitic atau disebut juga dengan teori asidogenik menjelaskan bahwa pembentukan karies gigi disebabkan oleh asam yang dihasilkan oleh aksi mikroorganisme terhadap karbohidrat. Sedangkan Menurut Teori Mamengko 2016, karies gigi merupakan penyakit yang menyerang jaringan keras gigi, yaitu email, dentin, pulpa, yang disebabkan oleh aktivitas jasad renik dalam suatu karbohidrat yang dapat diragikan. Menurut Teori Martapura 2012, dampak yang terjadi bila sejak awal sudah mengalami karies adalah selain fungsi gigi sebagai pengunyah yang terganggu, rewel, gusi bengkak anak juga akan mengalami gangguan dalam menjalankan aktivitasnya sehari-hari, sehingga anak tidak mau makan dan akibatnya yang lebih parah bisa terjadi malnutrisi, anak tidak dapat belajar karena kurang berkonsentrasi sehingga akan mempengaruhi kecerdasannya. Menurut peneliti timbulnya anak-anak yang mengalami kejadian karies gigi dikarena anak-anak suka mengkonsumsi makanan yang mengandung karbohidrat berlebihan sehingga dapat menimbulkan karies gigi yang dideritanya. Timbulnya karies terhadap anak-anak kurangnya pengetahuan orang tua tentang makanan yang dikonsumsi oleh anaknya disekolah maupun di rumah dengan 
karbohidat yang berlebih yang dapat menyebaabkan kejadian karies gigi.

\section{PENUTUP}

Hasil penelitian menunjukkan ada hubungan antara frekuensi konsumsi karbohidrat dengan kejadian karies gigi $(P$ Value: 0,01) diharapkan para orang tua iswasiswa TK Asmaul Husna Arosbaya Bangkalan Madura lebih menyadari dan lebih mengurangi konsumsi makanan yang mengandung karbohidrat yang berlebihan.

\section{UCAPAN TERIMA KASIH}

Ucapan terima kasih kami berikan kepada Kepala Sekolah TK Asmaul Husna Arosbaya Bangkalan, atas kesempatan, dan bimbingan dalam penelitian.

\section{DAFTAR PUSTAKA}

Dewanti, 2012. Hubungan Tingkat Pengetahuan Tentang Kesehatan Gigi Dengan Prilaku Perawatan Gigi Pada Anak Usia Sekolah Di SDN Pondok Cina 4 Depok. Diakses Pada Tanggal 5 Oktober 2019 Melalui hhtp.//lib.Ui.ac.id/

Galuh, A.I. 2018. Gigi Sehat, Anak Cerdas. Yogyakarta : Penerbit CV Budi Utama

Hidayat, R dan Astrid, T. 2016. Kesehatan Gigi dan Mulut. Yogyakarta : Penerbit Andi Yogyakarta

Khila, F.N. 2017. Metabolisme Karbohidrat Tujuan Biokimia dan Patologis. Malang : Penerbit Buku UB Press

Nursalam, 2013. Metodelogi Penelitian Ilmu Keperawatan. Salemba Medika : Jakarta

Purwanto, 2015. Kedokteran Gigi Klinik. EGC : Jakarta

Ramayanti, S. dan Idral Purna Karya. 2013. Peran Makanan Terhadap Kejadian Karies Gigi. Jurnal Kesehatan Andalas Seagai Fokus Infeksi. Penerbit PT Elex Media Komputindo Kelompok Gramedia : Jakarta 